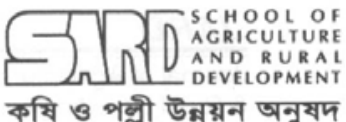

কৃষि ও পब्ली উन्नয়न অनूষদ
Available online at http://www.banglajol.info/index.php/jard
J ARD

Journal of Agriculture \& Rural Development

\title{
Agro-Economic Performance of Jackfruit-Pineapple Agroforestry System in Madhupur Tract
}

\author{
M. K. HASAN ${ }^{1 *}$, M. M. AHMED ${ }^{2}$ \& M. G. MIAH ${ }^{3}$ \\ ${ }^{1}$ On Farm Research Division, Bangladesh Agricultural Research Institute, Gazipur-1701, Bangladesh \\ ${ }^{2}$ Training and Communication Wing, Bangladesh Agricultural Research Institute, Gazipur-1701, Bangladesh \\ ${ }^{3}$ Department of Agroforestry and Environment, Bangabandhu Sheikh Mujibur Rahman Agricultural \\ University, Gazipur, Bangladesh
}

\begin{abstract}
A survey was carried out in two villages of Durgapur union under Kapasia upazila of Gazipur district during January to March, 2005 to investigate profitability, problems and management system of practicing jackfruit-pineapple agroforestry practice. Result revealed that the existing jackfruit-pineapple agroforesty system is profitable and has a great contribution to the meet up of nutritional demand. There is a scope of adopting improved management practices and it may increase the total production. Among the various problems, jackfruit trunk borer is the major. Measures against insects, bat, hedgehog, squirrel etc., use of popular cultivar and training on improved management practices for development of jackfruit-pineapple agroforestry system were suggested to overcome these problems.
\end{abstract}

Key words: Agro-economic performance, jackfruit-pineapple agroforestry system.

\section{INTRODUCTION}

Agroforestry is a collective name for land-use systems and technologies where woody perennials (trees, shrubs, palms, bamboos etc.) are deliberately used on the same land-management units as agricultural crops and/or animals, in some form of spatial arrangement or temporal sequence (Lundgren and Raintree, 1982). Through agroforestry, important forest products and desirable forest environment may be obtained almost everywhere in the country (Manandhar, 1986). Jackfruit (Artocarpus heterophyllus Lam K.) is a multipurpose tree with a great importance for its fruit, timber, fodder and fuel wood. It is the national fruit as it is consumed by all classes of rural Bangladeshi people as well as it is native to the country (Rashid et al., 1987). Jackfruit is rich in vitamin A and C, contains moderate qualities of minerals and high qualities of protein, calcium, thiamin, riboflavin and carotene than banana, but less in nutrition to mango (Hossain et al., 1979).

Jackfruit is the principal fruit tree in Madhupur tract. It was identified as an important cashgenerating crop (Ahmed, 1999). Pineapple (Annanas comosus) is a common fruit in Bangladesh and it is a good source of vitamin A, B and C (Mondal, 2000). Basher (1999) found that 50 per cent of all households at Kapasia upazila under Gazipur district had pineapple gardens adjoining their homesteads mostly under the jackfruit trees. In this system, farmers believe that the partial shade of the trees improves the physical environment for pineapple that ultimately enhances the yield and

* Corresponding author: Scientific Officer, OFRD, BARI, Gazipur-1701, Cell: 01818410770, E-mail: kamrulnk@yahoo.com

(C) 2008 School of Agriculture and Rural Development, Bangladesh Open University, All rights reserved. 


\section{K. Hasan et al.}

quality of the latter. The jackfruit trees not only provide suitable ecology for the under storey crop but also produce other basic requirements of the growers such as food, fodder, fuel wood and timber. The average annual net returns of the traditional agrisilvicultural practices were found much higher than the agriculture (Abedin and Quddus, 1991). But the farmers are loosing their interest in such kind of agroforestry system due to some problems. Agroforestry system, more particularly, jackfruit-pineapple system may be popular among the farmers if some positive steps are taken for improving its production and different management practices. Before giving any policy options on the development of jackfruitpineapple agroforestry system as well as increasing jackfruit and pineapple production, relevant and adequate information on various aspects of the system at farm level is required. But such information is very limited due to lack of adequate research in the field. Therefore, the present study was undertaken to assess and describe the production practices of jackfruit-pineapple agroforestry system and its profitability, to identify the major constraints and potentials of jackfruit-pineapple agroforestry system.

\section{MATERIALS AND METHODS}

The study was carried out at Kapasia upazila of Gazipur district during January to March, 2005. Two villages under Durgapur union were purposively selected for farm level data collection. As the sampling farm was not readily available, a total of 60 farmers were selected randomly to collect primary data. A pre-design and pre-tested survey schedule was used for this purpose. The collected data were summarized and scrutinized carefully for statistical analysis using SPSS 10.0, computer software for analyzing data. In order to evaluate the jackfruit-pineapple agroforestry system, investment analyses were carried out considering the timing of benefit and costs throughout the rotation period of jackfruit-pineapple systems. Three discounted measures as suggested by Guittinger (1982) and followed by Hasan et al. (1991) and Uddin and Hasan (2003), among others for project appraisal were adopted in this study.

\section{RESULTS AND DISCUSSION}

\section{Common production practices by the farmers in jackfruit-pineapple agroforestry system}

\section{Time of planting}

All the respondent farmers opined that they plant jackfruit sapling during the rainy season i.e. in the month of July-August and the pineapple suckers in the month of September with about 120 saplings per hectare for jackfruit and about 30000 suckers per hectare for pineapple, respectively (Table 1).

\section{Application of fertilizer}

Usually farmers do not apply fertilizers. Some farmers use fertilizers and manure during the planting time. They used $10 \mathrm{~kg}$ cowdung, $250 \mathrm{~g}$ urea, $250 \mathrm{~g}$ TSP and $250 \mathrm{~g}$ of MP during the planting of jackfruit sapling. None of the farmers were found to apply fertilizers after the establishment of sapling. Therefore, immense scope and prospects exists for increasing the productivity of jackfruit through adopting appropriate fertilizer management practices. Although experimental evidence on nutritional requirement of jackfruit is not available, application of farmyard manure at $37 \mathrm{~kg}$ per plant in first year, $750 \mathrm{~g}$ ammonium sulfate, $625 \mathrm{~g}$ single superphosphate and $300 \mathrm{~g}$ muriate of potash per plant per year in the second and third year of planting and in the fourth year an increased dose of $938 \mathrm{~g}$ ammonium sulfate, $781 \mathrm{~g}$ single superphosphate and $375 \mathrm{~g}$ of muriate of potash were found to increase growth, flowering and fruiting in jackfruit (Mukherjee et al., 1983). At the age of 6-10, 25-50 $\mathrm{kg}$ cowdung, 500-700 g urea, 300-600 g TSP and 300-400 g MP and in plants older than 10 years, $60-110 \mathrm{~kg}$ cowdung, $1-1.2 \mathrm{~kg}$ urea, $0.8-1.0 \mathrm{~kg}$ TSP and $1 \mathrm{~kg}$ of MP may be applied per tree (Mondal, 2000). As pineapple removes $123 \mathrm{~kg}$ of nitrogen, $33 \mathrm{Kg}$ of phosphorus and $308 \mathrm{Kg}$ of potash from one hectare of land yielding a crop of 40 tones (Sen, 1990), it requires a substantial amount of nutrients. India recommended $600-400-600 \mathrm{Kg} / \mathrm{ha}$ of $\mathrm{N}, \mathrm{P}_{2} \mathrm{O}_{5}$ and $\mathrm{K}_{2} \mathrm{O}$ for pineapple in (Roy et al., 1986). Jackfruit and pineapple are grown in rainfed condition.

\section{Weeding}

Thirteenth 'Bhadra' (28th August) is the day when farmers start weeding pineapple orchard. They believe that it might bring curse if they do not start weeding on that day. 
Agro-economic performance of jackfruit-pineapple agroforestry system in Madhupur tract

\section{Harvesting time of the products}

Usually the farmers harvested the jackfruit from April to July and in some cases up to September and pineapple from mid May to July.

Table 1. Production practice of jackfruit-pineapple agroforestry system in the study area

\begin{tabular}{lcc}
\hline Item & Jackfruit & Pineapple \\
\hline Planting period & July-August & September \\
Number of plants per ha (approximately) & 120 & 30,000 \\
Fertilizer per pit during planting & & \\
$\quad$ Organic matter & $10 \mathrm{~kg}$ & \\
$\quad$ Urea & $250 \mathrm{~g}$ & \\
TSP & $250 \mathrm{~g}$ & \\
MP & $250 \mathrm{~g}$ & August-September \\
Weeding & & \\
Pruning & After harvesting & Mid May to July \\
Harvesting period & April to July & Around 12000 \\
Fruit yield (No./ha.) & Around 2400 & Sucker 30000 \\
By product yield (per ha.) (approximately) & & \\
\hline
\end{tabular}

\section{Sources of planting materials}

Own sources plus local market are the prime source (60\%) for jackfruit saplings followed by own source plus neighbor plus local market (32\%). A very few farmers also purchased saplings from the private nursery.

\section{Selling of the products}

Most of the farmers (40\%) sell their product to the middlemen (Bepari) at their farm gate followed by Bepari and local market (31.67\%). Only $28.33 \%$ of the farmers, who were mostly under marginal and small category, sell their product at local market.

\section{Some features about jackfruit-pineapple agroforestry system}

\section{Age and fruit bearing of jackfruit trees}

The age of jackfruit trees varied from farm to farm. Most of the trees (35.68\%) were at the age of 21-40 years followed by 5-10 years (27.15\%) (Table 2). In few farms, the trees under 5 and $<40$ years were not found. Rasel (2004) found that maximum numbers of trees (38\%) were under the age of 16 to 25 followed by 26 to 40 years (36.6\%) in three villages of Sreepur upazila under Gazipur district. It is revealed that $23.19,85.59,88.09$ and $86.44 \%$ were fruit bearing trees under the age groups of $<5$ years, 5-20 years, $21-40$ years and above 40 years per hectare respectively. It was found that the trees under the five year bear fruits to some extent. Amin (2004) reported that the first fruiting starts in the jackfruit tree at the age of 4 years although Sammadar (1990) stated that the trees usually bear fruit at 7-8 years. In a study, Asaduzzaman (1993) found that 61.23 to $95.31 \%$ fruit bearing trees were $>5$ years old in different categories of farms. All the trees may not bear fruits due to physical factors (Mondal, 2000).

Table 2. Number of jackfruit trees in the jackfruit-pineapple orchards (per hectare)

\begin{tabular}{|c|c|c|c|c|c|c|c|c|}
\hline \multirow{2}{*}{$\begin{array}{l}\text { Tree } \\
\text { category }\end{array}$} & \multicolumn{4}{|c|}{ Number of jackfruit trees in orchard } & \multicolumn{4}{|c|}{$\begin{array}{l}\text { Number of fruit bearing jackfruit trees } \\
\text { in orchard }\end{array}$} \\
\hline & Minimum & Maximum & Average & S.D. & Minimum & Maximum & Average & S.D. \\
\hline$<5$ ye & 00 & 75 & 19.70 & 18.43 & 00 & 60 & 4.57 & 11.67 \\
\hline $5-20$ years & 12 & 115 & 38.18 & 21.39 & 12 & 98 & 32.68 & 17.84 \\
\hline 21- 40 years & 15 & 115 & 39.37 & 20.23 & 13 & 96 & 34.68 & 17.28 \\
\hline$>40$ years & 00 & 75 & 20.13 & 20.16 & 00 & 67 & 17.40 & 18.14 \\
\hline
\end{tabular}

On an average, highest numbers of fruit (32.93) were found in the trees aged of 21 to 40 years followed by 5 to 20 years-old trees ( 28.47 fruit per tree). Number of fruit declined in case of tree 
$>40$ years (24.22). Few trees bear fruits at the age of 5 years. Amin (2004) found that the trees aged between 18 to 20 years bear on an average of 35.66 fruits per tree followed by the tree of 12 to 14 years (17.33 fruits per tree). Asaduzzaman (1993) observed that a jackfruit tree bears 21 to 27 fruits on an average.

\section{Pattern of jackfruit and pineapple utilization}

Pattern of jackfruit and pineapple utilization in different farm categories is presented in the Table 3 and 4 , respectively. It was found that the number of jackfruits consumed per family varied from 81 to 173 depending upon the farm category. It varied mainly with the family size- larger family consumed more fruits. In terms of percentage, the consumption decreased with increasing the farm size which might be due to increased production in bigger farm. The percentage of sold fruits gradually increased in bigger farms. The wastage percentage was 6.36 to 6.66. Wastage of jackfruit caused mostly due to insect, diseases, vertebrates and natural calamities. On an average, 8.54, 80.11, 4.80 and $6.55 \%$ of the total production of jackfruit were consumed, sold, distributed (to the relatives, neighbors, mosques and others) and wasted, respectively. Asaduzzaman (1993) also found that $20-25,60-75$ and $5-10 \%$ of the total production of jackfruit were consumed, sold and distributed by the growers in case of homestead trees in different categories of farm, respectively. Ahmed (2002) found that the consumption, sale, distribution and wastage were $16.24,74.706 .49$ and $2.57 \%$ of the total production, respectively of the growers.

Table 3. Pattern of utilization of jackfruit (number) in different farm categories

\begin{tabular}{lccccc}
\hline Farm category & $\begin{array}{c}\text { Production } \\
\text { (number/farm) }\end{array}$ & $\begin{array}{c}\text { Consumed by the Sold by the farm } \\
\text { farm family }\end{array}$ & Distribution & Wastage \\
\hline Marginal & 733 & $100(13.64)$ & $550(75.03)$ & $33(4.5)$ & $50(6.52)$ \\
Small & 783 & $81(10.23)$ & $608(76.77)$ & $41(5.24)$ & $53(6.66)$ \\
Medium & 1092 & $95(8.66)$ & $879(80.13)$ & $49(4.47)$ & $74(6.75)$ \\
Large & 2624 & $173(6.69)$ & $2167(83.87)$ & $117(4.46)$ & $167(6.36)$ \\
\hline Overall (per farm) & 1312 & $112(8.54)$ & $1051(80.11)$ & $63(4.80)$ & $86(6.55)$ \\
\hline
\end{tabular}

Figures in the parentheses indicates the percentage

The consumption number of pineapple varied form 132 to 183 depending upon the farm size (Table 4). Major portion of the production (80.37 to $93.35 \%$ ) is sold by all categories of farms. Distribution to relatives, neighbors, mosques and others varied from 1.42 to 5.17 percent. Due to various factors like hedgehog, animals and also diseases caused the wastage from 3.67 to $5.97 \%$ of the total production in different farms. Aziz (1976) observed that 5 percent of pineapple fruit was wasted in the process of bringing from producers to ultimate consumers. On an average, 2.64, 90.74, 2.12 and $4.51 \%$ of the total production were consumed, sold, distributed and wasted, respectively.

Table 4. Pattern of utilization of pineapple (number) in different categories of farmers

\begin{tabular}{lccccc}
\hline Farm category & $\begin{array}{c}\text { Production } \\
\text { (number/farm) }\end{array}$ & $\begin{array}{c}\text { Consumed by } \\
\text { the farm family }\end{array}$ & $\begin{array}{c}\text { Sold by the } \\
\text { farm }\end{array}$ & Distribution & Wastage \\
\hline Marginal & 1652 & $150(8.61)$ & $1400(80.37)$ & $90(5.17)$ & $102(5.86)$ \\
Small & 4362 & $132(3.02)$ & $3941(90.3)$ & $90(2.06)$ & $199(4.56)$ \\
Medium & 5183 & $144(2.80)$ & $4593(89.46)$ & $139(2.71)$ & $307(5.97)$ \\
Large & 11783 & $183(1.55)$ & $11000(93.35)$ & $167(1.42)$ & $433(3.67)$ \\
\hline Overall (per farm) & 5768 & $152(2.64)$ & $5234(90.74)$ & $122(2.12)$ & $260(4.51)$ \\
\hline
\end{tabular}

Figure in the parenthesis indicates the percentage

\section{Area of jackfruit-pineapple orchard in the total cultivable land}

The average cultivable land, area under jackfruit-pineapple orchard and percent of jackfruit-pineapple orchard in the total cultivable land are presented in the Table 5. It was also found that all the farms devoted 15.89 to $47.37 \%$ of their cultivable land for jackfruit-pineapple orchard. A strong, positive and significant correlation was also found between the cultivable area and the area under jackfruit-pineapple orchard $\left(r=0.765^{\star \star}\right)$ and between the area under jackfruit-pineapple orchard and income $\left(r=0.595^{\star \star}\right)$. 
Agro-economic performance of jackfruit-pineapple agroforestry system in Madhupur tract

Table 5. Area of jackfruit-pineapple orchard in the total cultivable land

\begin{tabular}{lccc}
\hline Farm category & $\begin{array}{c}\text { Cultivable land per } \\
\text { farm (ha) }\end{array}$ & $\begin{array}{c}\text { Area under } \\
\text { jackfruit-pineapple } \\
\text { orchard (ha) }\end{array}$ & $\begin{array}{c}\text { Percent of jackfruit-pineapple } \\
\text { orchard in the total cultivable } \\
\text { land per farm }\end{array}$ \\
\hline Marginal & 0.38 & 0.18 & 47.37 \\
Small & 0.84 & 0.30 & 37.04 \\
Medium & 1.45 & 0.49 & 33.79 \\
Large & 7.05 & 1.12 & 15.89 \\
\hline
\end{tabular}

\section{Nutritional contribution of jackfruit-pineapple orchard to the farmers}

Jackfruit-pineapple agroforestry systems can play a great role in alleviating our under nutritional problems. Contribution of jackfruit-pineapple orchard in nutrition is presented in the Table 6.

Nutritional value of jackfruit and pineapple was calculated considering the following points:

Average farm family sizes: 6.42 . (at the study area found)

RDA (Recommended Dietary Allowance) was followed as Rashid (1999) for middle age of 20-49.

The number of jackfruit consumption: 112 (Table 3)

The average weight of mature and ripe jackfruit ranges from 3.24 to $7.39 \mathrm{~kg}$ (Hossain and Haque, 1977), considering a fruit is about $5 \mathrm{~kg}$.

Duration of fruiting (jackfruit): 4 months.

Edible portion of a cell of jackfruit: 30\% (Vaidya, 1982)

The number of consumption of pineapple: 152 (Table 4)

Duration of fruiting (pineapple): 2.5 months.

Average weight of a pineapple fruit: $739 \mathrm{~g}$ (Hossain, 1999)

The required energy was considered as $2212 \mathrm{~K}$. cal./capita/day (FAO, 1985)

Table 6. Nutritional contribution from jackfruit-pineapple orchard in the recommended dietary allowance (per family per day)

\begin{tabular}{|c|c|c|c|c|c|c|c|c|c|}
\hline & $\begin{array}{c}\text { Energy } \\
\text { (K. Cal.) }\end{array}$ & $\begin{array}{l}\text { Protein } \\
(\mathrm{mg})\end{array}$ & $\begin{array}{l}\text { Vit. A } \\
\text { (I.U.) }\end{array}$ & $\begin{array}{l}\text { Thiamin } \\
(\mathrm{mg})\end{array}$ & $\begin{array}{c}\text { Riboflav } \\
\text { in (mg) }\end{array}$ & $\begin{array}{l}\text { Niacin } \\
(\mathrm{mg})\end{array}$ & $\begin{array}{l}\text { Vit. C } \\
\text { (mg) }\end{array}$ & $\begin{array}{l}\text { Calcium } \\
\text { (mg) }\end{array}$ & $\begin{array}{l}\text { Iron } \\
\text { (mg) }\end{array}$ \\
\hline Jackfruit & 1234 & 26.6 & 2450 & 0.42 & 1.82 & 5.6 & 98 & 280 & 7 \\
\hline Pineapple & 585 & 9 & 900 & 0.9 & 0.45 & 4.5 & 180 & 195 & 12 \\
\hline Total & 1819 & 35.6 & 3350 & 1.32 & 2.27 & 10.1 & 278 & 475 & 19 \\
\hline $\begin{array}{l}\text { RDA (for average } \\
\text { family size) }\end{array}$ & 14200 & 334 & 4815 & 9 & 9 & 118 & 193 & 2889 & 58 \\
\hline$\%$ of RDA & 13 & 11 & 70 & 15 & 25 & 9 & 144 & 16 & 33 \\
\hline
\end{tabular}

It was found (Table 6) that jackfruit-pineapple orchard has great contribution on family nutrition. The contribution of jackfruit-pineapple orchard for a farm family in recommended dietary allowance of energy, protein, vitamin A, thiamin, riboflavin, niacin, vitamin C, calcium and iron was 13, 11, 70, $15,15,25,9,144,16$ and $33 \%$, respectively during cropping season. It revealed that daily requirement of vitamin $\mathrm{C}$ can fully satisfied solely by jackfruit-pineapple.

\section{Utilization of sale proceeds from jackfruit and pineapple}

The income generated from selling of jackfruit and pineapples were used for different purposes. On an average, major portion of sale proceeds were found to be used for meeting the daily household requirements $(80 \%)$ followed by educational expenditure $(27 \%)$, buying cloths and other necessaries (23\%), loan repayment (22\%), medical expenses $(20 \%)$, buying agricultural equipments (17\%), household construction (13\%), marriage ceremony $(7 \%)$, and business investment $(7 \%)$. Larger group of farmers used their sale proceeds mainly in construction works while the poorer groups used it in daily expenditure, medical expenses, loan repayment etc. 
Other tree association: Besides the jackfruit trees, there are various types of trees like Sal (Shorea robusta), Teak (Tectona grandis), Akasmony (Acacia auriculiformis), Mango (Mangifera indica), Litchi (Licthi chinensis), Blackberry (Syzygium cumini), Sonalu (Cassia fistula), Koroi (Albizia spp.), Raintree (Samanea saman), Mahogony (Swietenia mahogoni), Garjan (Dipterocarpus spp.), Giga (Odina wodier), Gamar (Gmelina arborea), etc. were found in the orchard. Farmers opined that the production of jackfruit as well as pineapple is declining due to introduction of timber species as a consequence of overcrowding of upper storey canopy.

\section{Economic performance of jackfruit-pineapple agroforestry system}

\section{Intertemporal budgeting for jackfruit-pineapple agroforestry system}

Intertemporal budgeting for jackfruit-pineapple agroforestry system is presented in Table 7. For intertemporal budgeting all costs incurred and benefits accrued from the trees have been taken into consideration. Initial cost incurred for jackfruit and pineapple plantation included saplings, suckers, bamboo stick, fertilizers, land and pit preparation and land rent which was Tk. 40158/ha. Jackfruit and pineapple became harvestable at the age of 4 and 2 years, respectively. During initial stage, cost was very high due to inputs. Benefits from Jackfruit-pineapple agroforestry production system started from second year of planting, which was Tk. 457449/ha. Benefit was increased with the passage of time. The benefit of second year and third year was constant due to no income from jackfruit.

Intertemporal budget for jackfruit-pineapple agroforestry production system showed that the cash flow in the first year was negative, but it became positive from second year and it continued in subsequent years (Table 7 ). At $12 \%$ discounted rate, gross cost, gross benefit and net present value were Tk. 303729/ha, 457449/ha and 153720/ha, respectively. Benefit cost ratio (1.51), net present value (Tk. 457449/ha) and internal rate of return (51\%) clearly indicated the profitability of Jackfruit-pineapple agroforestry production system. The benefit cost ratio indicated that if a farmer invests Tk. 100, he would get Tk. 151.

Table 7. Benefit cost ratio of jackfruit-pineapple production for 25 years

\begin{tabular}{|c|c|c|c|c|c|c|c|c|}
\hline $\begin{array}{l}\text { Age of } \\
\text { orchard } \\
\text { (year) }\end{array}$ & $\begin{array}{c}\text { Gross } \\
\text { cost } \\
\text { (Taka) }\end{array}$ & $\begin{array}{l}\text { Gross } \\
\text { return } \\
\text { (Taka) }\end{array}$ & $\begin{array}{c}\text { Cash } \\
\text { flow (CF) } \\
\text { (Taka) }\end{array}$ & $\begin{array}{l}\text { Discounted } \\
\text { CF at 30\% } \\
\text { DR (Taka) }\end{array}$ & $\begin{array}{l}\text { Discounted } \\
\text { CF at } 40 \% \\
\text { DR (Taka) }\end{array}$ & $\begin{array}{c}\text { Discounted } \\
\text { gross cost } \\
\text { at } 12 \% \text { DR } \\
\text { (Taka) }\end{array}$ & $\begin{array}{c}\text { Discounted } \\
\text { gross return } \\
\text { at } 12 \% \text { DR } \\
\text { (Taka) }\end{array}$ & $\begin{array}{c}\text { Net Present } \\
\text { Value of Tk. } \\
\text { at } 12 \% \mathrm{DR} \\
\text { (Taka) }\end{array}$ \\
\hline 1 & 40158 & 0 & -40158 & -40158 & -40158 & 40158 & 0 & -40158 \\
\hline 2 & 22800 & 35000 & 12200 & 9382 & 8711 & 20360 & 31255 & 10895 \\
\hline 3 & 22800 & 35000 & 12200 & 7222 & 6222 & 18172 & 27895 & 9723 \\
\hline 4 & 23998 & 35700 & 11702 & 5324 & 4260 & 17087 & 25418 & 8332 \\
\hline 5 & 24148 & 36000 & 11852 & 415 & 3082 & 15358 & 22896 & 7538 \\
\hline 6 & 26072 & 39000 & 12928 & 3478 & 2405 & 14783 & 22113 & 7330 \\
\hline 7 & 28072 & 43000 & 14928 & 3090 & 1985 & 14233 & 21801 & 7568 \\
\hline 8 & 30920 & 47000 & 16080 & 2557 & 1528 & 13976 & 21244 & 7268 \\
\hline 9 & 32920 & 51000 & 18080 & 2224 & 1229 & 13300 & 20604 & 7304 \\
\hline 10 & 36192 & 55000 & 18808 & 1768 & 903 & 13065 & 19855 & 6790 \\
\hline 11 & 38192 & 59000 & 20808 & 1519 & 728 & 12298 & 18998 & 6700 \\
\hline 12 & 41040 & 63000 & 21960 & 1230 & 549 & 11778 & 18081 & 6303 \\
\hline 13 & 43040 & 67000 & 23960 & 1030 & 431 & 11061 & 17219 & 6158 \\
\hline 14 & 45888 & 71000 & 25112 & 829 & 326 & 10508 & 16259 & 5751 \\
\hline 15 & 47888 & 75000 & 27112 & 678 & 244 & 9817 & 15375 & 5558 \\
\hline 16 & 51160 & 79000 & 27840 & 529 & 167 & 9362 & 14457 & 5095 \\
\hline 17 & 53160 & 83000 & 29840 & 448 & 149 & 8665 & 13529 & 4864 \\
\hline 18 & 56432 & 87000 & 30568 & 367 & 92 & 8239 & 12702 & 4463 \\
\hline 19 & 58432 & 91000 & 32568 & 293 & 65 & 7596 & 11830 & 4234 \\
\hline 20 & 60432 & 95000 & 34568 & 242 & 69 & 7010 & 11020 & 4010 \\
\hline 21 & 62280 & 97000 & 34720 & 174 & 35 & 6477 & 10088 & 3611 \\
\hline 22 & 63280 & 99000 & 35720 & 143 & 36 & 5885 & 9207 & 3322 \\
\hline 23 & 64280 & 101000 & 36720 & 110 & 37 & 5335 & 8383 & 3048 \\
\hline 24 & 65280 & 103000 & 37720 & 75 & 0 & 4831 & 7622 & 2791 \\
\hline 25 & 66280 & 903000 & 836720 & 1673 & 0 & 4374 & 59598 & 55224 \\
\hline Total & & & & 4641 & -6906 & 303729 & 457449 & 153720 \\
\hline
\end{tabular}

$\mathrm{PV}=$ present value, $\mathrm{DR}=$ discounted rate

Result: BCR at $12 \%=1.51$, NPV at $12 \%=$ Tk. 153720 per hectare, IRR is $51 \%$ 
Agro-economic performance of jackfruit-pineapple agroforestry system in Madhupur tract

\section{Sensitivity analysis}

Sensitivity analysis of the jackfruit-pineapple agroforestry system for 25 years (Table 8) were done considering-

(i) Cost increased by $10 \%$

(ii) Gross return reduced by $10 \%$ and

(ii) Cost increased by $10 \%$ and gross return reduced by $10 \%$.

Table 8. Sensitivity analysis of the jackfruit-pineapple orchard

\begin{tabular}{lccc}
\hline Sensitivity analysis considering & Benefit cost ratio & $\begin{array}{c}\text { Net present } \\
\text { value }\end{array}$ & $\begin{array}{c}\text { Internal rate of } \\
\text { return }\end{array}$ \\
\hline (i) Cost increased by $10 \%$ & 1.37 & Tk. 123347 & 35.5 \\
(ii) Gross return reduced by 10\% & 1.36 & Tk. 107975 & 34.2 \\
(iii) Cost increased by $10 \%$ and & 1.23 & Tk. 77602 & 26.5 \\
$\quad$ gross return reduced by 10\% & & & \\
\hline
\end{tabular}

Sensitivity analysis showed that BCR and IRR might be very close if cost increased by $10 \%$ or gross return reduced by $10 \%$. BCR, NPV and IRR may be at 1.37, Tk. 123347 and 35.5 respectively, when cost increased $10 \%$. Considering gross return reduced by $10 \%$ the BCR, NPV and IRR were 1.36, Tk.107975 and 34.2 while the combination of cost increases by $10 \%$ and gross return reduce by $10 \%$, the BCR, NPV and IRR might be 1.23 , Tk. 77602 and 26.5 , respectively, which shows that the practice is almost sure to remain profitable despite the uncertainties associated with the estimates of costs and returns used in the discounted benefit-cost analysis.

\section{Problems faced by the farmers in practicing jackfruit-pineapple agroforestry system}

The respondents face various problems in practicing jackfruit-pineapple agroforestry system in the area. The major problems were listed in Table 9.

\section{Insects}

All farmers opined that 'jackfruit trunk borer' caused severe damage to the jackfruit production. Jackfruit fruit borer also caused damage to fruit. Rasel (2004) recorded $25.3 \%$ of jackfruit trees were infested by borer in three villages under Sreepur upazila. This type of severity was prominent during last 10-15 years due to introduction of timber trees in the orchard. Initially, borer (caterpillar) attacks the trunk creating a hole. After a few years of infestation, the trees die. In case of fruit borer, the reddish brown larvae bore into the fruit and destroy them. The damage by borer is locally called 'cancer'. As a control measure, some farmers use cowdung at the infested site. Alam (1974) recommended the following control measures to control the trunk borer:

i) The infested tree should be examined and the beetles and grubs whenever found are to be collected and destroyed.

ii) Paradichlorobenzene may be introduced into the holes of borers and the holes may be sealed up with mud.

\section{Squirrel and Bat}

Squirrel and bat attack the jackfruit during the ripening stage. They make wounds on the ripe fruit which reduces the market value of the fruit. Seventy five and $55 \%$ of the respondents expressed this problem of jackfruit due to damage by squirrel and bat, respectively.

\section{Hedgehog}

As pineapple is a good source of food for hedgehog, it causes severe damages to pineapple. During daytime, it remains hidden in the holes and come out at night. Twenty-four farmers (40\%) claimed that it was problem to pineapple. 


\section{Diseases}

About $43 \%$ of the farmers claimed that disease causes damage to the jackfruit-pineapple agroforestry system. Fruit drop due to 'Rhizopus rot' was identified as major disease in jackfruit. The rot starts near the stalk end which gets covered with the mycelium in case of small fruit. Spray application of Dithane M45 (Mancozeb $75 \%$ W.P.) at $0.2 \%$ and Bavistin (Carbendazim) at $0.05 \%$, three times at 14 day intervals starting in early March give the best control (Gupta and Pandey, 1985). 'Fruit rot' causes damage notably to pineapple when fruits are left too long before processing and become over-ripe. Dipping of the fruit stalk in benzoic acid is very effective to control of the fungus. The farmers did not take any control measures against the diseases due to lack of knowledge as well as high price of chemicals.

\section{Low price of the products}

That was applicable for pineapple. The prevailing cultivar i.e. 'ghorasal' generally produced in that area is not much as popular due to its sour taste. Due to less demand of 'ghorasal' cultivar, its price is low as compared to other cultivars like 'honey queen' and 'giant kew'.

\section{Lack of capital}

During the establishment of jackfruit-pineapple orchard, huge amount of capital is needed to purchase of inputs. Moreover, most of the farmers were under the small and medium farm categories and their annual income was not over Tk. 85000. Thirty five (58\%) farmers expressed that lack of capital was a problem for the development of the orchard.

\section{High price of inputs}

Due to the high price of insecticides, fungicides and fertilizers, farmers were reluctant to use those. Forty-five (i.e. $75 \%$ ) of the farmers consented such kind of problem.

\section{Lack of storing facility}

Due to lack of storage facility, farmers were not able to store the harvested jackfruit and pineapple any longer. Fifty percent of the farmers claimed that lack of storage facility was a problem.

Besides these problems, poor communication, labor crisis, stealing of fruit at the harvesting time, lack of skilled manpower, insufficient extension service, natural calamities etc. were the common problems faced by the farmers in the orchard.

Table 9. Problems faced by the farmers in practicing jackfruit-pineapple agroforestry system

\begin{tabular}{|c|c|c|c|c|}
\hline \multicolumn{2}{|r|}{ Type of problem } & No. of respondents & Percent of respondents & Rank order \\
\hline \multirow[t]{6}{*}{ A. } & Biological problem & & & \\
\hline & i) Insects & 60 & 100 & $1^{\text {st }}$ \\
\hline & ii) Squirrels & 45 & 75 & $3^{\text {rd }}$ \\
\hline & iii) Bats & 33 & 55 & $5^{\text {th }}$ \\
\hline & iv) Hedgehogs & 24 & 40 & $9^{\text {h }}$ \\
\hline & v) Diseases & 26 & 43 & $8^{\text {th }}$ \\
\hline \multirow[t]{4}{*}{ B. } & Economic problem & & & \\
\hline & i) Low price of products & 51 & 85 & $2^{\text {nd }}$ \\
\hline & ii) Lack of capital & 35 & 58 & $4^{\text {th }}$ \\
\hline & iii) High price of inputs & 45 & 75 & $3^{\text {rd }}$ \\
\hline \multirow[t]{4}{*}{ C. } & Marketing problems & & & \\
\hline & i) Lack of storing & 30 & 50 & $6^{\text {th }}$ \\
\hline & ii) Poor communication & 28 & 47 & $7^{\text {th }}$ \\
\hline & iii) Labour crisis & 23 & 38 & $10^{\text {th }}$ \\
\hline \multirow[t]{4}{*}{ D } & Social problem & & & \\
\hline & i) Problem of theft & 12 & 20 & $12^{\text {th }}$ \\
\hline & ii) Lack of skilled manpower & 14 & 23 & $11^{\text {th }}$ \\
\hline & iii) Insufficient extension service & 12 & 20 & $12^{\text {th }}$ \\
\hline E. & Natural calamities & 9 & 15 & $13^{\text {th }}$ \\
\hline
\end{tabular}


Agro-economic performance of jackfruit-pineapple agroforestry system in Madhupur tract

\section{Farmers' suggestions for development of Jackfruit-pineapple agroforestry system}

Respondent farmers gave their opinions for jackfruit-pineapple agroforestry system. These were taking proper control measures against insects, bats, squirrels and hedgehogs, introduction of popular pineapple cultivar, development of marketing system, improved management practices, arrangement of training and optimum fertilizer use etc.

\section{CONCLUSION}

From the above study it might be concluded that farmers use the planting materials from their own sources in most cases. They do not use fertilizer to the orchard after establishing the plants. There is a scope of different management practices specially balanced dose of fertilizer that can boost up the production. During cropping season, the daily requirement of vitamin $C$ was fully satisfied but in case of other nutrients (eg. Riboflavin, Iron, Calcium, Thiamin, Protein etc.) requirement was partially fulfilled by jackfruit and pineapple. Economic analysis showed the profitability of the system. Some problems like jackfruit trunk borer, low price of pineapple, high price of inputs, attack of bats and squirrels on jackfruit and hedgehogs on pineapple etc. are being jeopardized the farmers to practice this system. There is a need to take measures to solve the problems as priority basis. Training on agroforestry is need for the orchard associates. Farmers and extension workers should be trained on improved management practices (fertilization, application of hormone etc.) to improve the productivity of jackfruit-pineapple agroforestry system. Steps should be taken to replace the local cultivar of pineapple with improved cultivar to increase productivity and profitability of the system. A sound marketing system should be developed. Besides, necessary processing plant should be established to prevent spoilage of fruits at the time of peak harvest. Appropriate research studies should be undertaken to develop control measures against the jackfruit borer.

\section{LITERATURE CITED}

Abedin, M. Z. and Quddus. M. A. 1991. Agroforestry system in Bangladesh with particular reference to economic and tenurial issues. In "Agroforestry in Asia and the Pacific". No. 1995/5. FAO regional office for Asia and the Pacific. Bangkok, Thailand. pp. 13-33.

Ahamed, F. 2002. Marketing and consumption of jackfruit in some selected areas of Mymensingh and Gazipur districts. Unpublished [MS Thesis], Department of Agricultural Economics, Bangabandhu Sheikh Mujibur Rahman Agricultural University, Gazipur. 86 pp.

Ahmed, M. F. U. 1999. Homestead Agroforestry in Bangladesh: A case study of Gazipur district. Unpublished [MS Thesis], Department of Agroforestry and Environment, Bangabandhu Sheikh Mujibur Rahman Agricultural University, Gazipur.

Alam, M. Z. 1974. "Insect and Mite Pest of Fruits and Fruit Trees in Bangladesh and Their Control" (Revised Edn.). B. G. Press, Dhaka. pp. 81-83.

Amin, M. M. 2004. Growth and yield of jackfruit at different ages in homestead and field conditions. Unpublished [MS thesis], Department of Agroforestry and Environment, Bangabandhu Sheikh Mujibur Rahman Agricultural University, Gazipur. 57 pp.

Asaduzzaman, S. M. 1993. Artocarpus heterophyllus: A potential species for homestead agroforestry in Bangladesh. Unpublished [MS Thesis], School of Agricultural and Forest Sciences, University College of North Wales, Bagor, Gnynedd.

Aziz, M. M. 1976. A study of pineapple marketing system in Mymensingh town. Unpublished [MSc Term paper], Department of Co-operative and Marketing, Bangladesh Agricultural University, Mymensingh.

Bashar, M. A. 1999. Homegarden Agroforestry: Impact on biodiversity conservation and household food security: A case study of Gazipur district, Bangladesh. Unpublished [MSc Thesis], Agricultural University of Norway, Oslo, Norway. 110 pp.

FAO. 1985. Energy and protein requirement. Report of a joint FAO/WHO expert committee. Who technical report series no. 24. Geneva.

Gupta, P. N. and Pandey, I. C. 1985. Prog Hort 17(4), 361-62. 
Guttinger, J. P. 1982. "Economic Analysis of Agricultural Projects" (Second Edn.). Johns Hopkins University Press, Baltimore.

Hasan, M. K., Miah, M. T. H. and Mondal, M. A. S. 1991. Returns from power tiller utilization in Bangladesh: An analysis of farm level data. Bang J Agril Econ 14(1), 87-97.

Hossain, M. and Haque, A. 1977. Bang Hort 5(1), 9-14.

Hossain, M. K. 1999. Shade effect on the yield and quality of pineapple in a jackfruit-pineapple agroforestry system. Unpublished [MS Thesis], Department of Agroforestry and Environment, Bangabandhu Sheikh Mujibur Rahman Agricultural University, Gazipur. 57 pp.

Hossain, M. M., Haque, A. and Hossain, M. 1979. Nutritive value of jackfruit. Bang J Agril 1(2), 9-12.

Khan, M. K. 1987. 12 October 1987. Collection and marketing problem in pineapple cultivation. In "The Daily Ittefaque", Dhaka.

Lundgren, B. O. and Raintree, J. B. 1982. Sustainable agroforestry. In "Agricultural Research for Development: Potentials and Challenges in Asia" (B. Nestel Ed.). ISNAR, The Hauge, pp. 3749.

Manandhar, P. K. 1986. "Introduction to Agroforestry in Bangladesh". Community Forestry Project Report, BGD/81/028, Banbhavan, Dhaka.

Mondal, F. M. 2000. "Production and Storage of Fruits" (in Bangla). Mrs. Afia Mondal, BAU campus, Mymensingh.

Mukherjee, S. K., Rao, D. P., Mukherjee, S., Ray, M. and Mohanty, B. B. 1983. Indian J Hort 40, 150-54.

Rasel, S. M. M. 2004. Identification of jackfruit trunk borer species and assessment of its severity of damage. Unpublished [MS Thesis], Department of Entomology, Bangabandhu Sheikh Mujibur Rahman Agricultural University, Gazipur.

Rashid, M. M. 1999. "Sabjibiggan" (Oliriculture, Second Ed.) Rashid publishing house, Jodebpur, Gazipur. 27 pp.

Rashid, M. M., Kadir, M. A. and Hossain, M. A. 1987. "Bangladesher Fal" (Fruits of Bangladesh). Rashid publishing house, Joydebpur, Gazipur.

Roy, R., Hossain, M., Mitra, S. K. and Bose, T. K. 1986. Maharashtra J Hort 3, 38-73.

Sammaddar, H. N. 1990. Jackfruit. In "Fruits: Tropical and subtropical" Bose, T. K. and S. K. Mitra (Eds.). Naya Prokash, Calcutta, India.

Sen, S. K. 1990. Pineapple. In "Fruits: Tropical and Subtropical" (Bose, T. K. and Mitra, S. K., Eds.). Naya Prokash, Calcutta. pp. 252-267.

Uddin, M. J. and Hasan. M. K. 2003. Homestead agroforestry in char areas at Noakhali: An economic analysis. Bang J Agril Res 28(3), 421-430.

Vaidya, Y. 1982. Master Plan for Forestry Sector, Nepal: The Forestry Resource of Nepal. HMG/ADB/FINNIDA, Kathmundu. 